\title{
A Summary of the Tourist Potential of Ferizaj
}

\author{
Halil Halili \\ PhD Candidate, Mediteran University, Faculty of Tourism, Bar, Monte Negro \\ Email: halilhalili@hotmail.com
}

\section{Doi:10.5901/ajis.2015.v4n2s2p63}

\begin{abstract}
Ferizaj is, without any doubts, one of the most interesting areas thanks to its wealth and natural beauties. Ferizaj has great potentials for tourism development, as a cultural one as well as to the nature and recreation. Among the potential of local tourism development are Sharri beautiful mountains, river valleys Nerodime, bifurcation, the union of two rivers etc. The different historical past has left numerous material monuments such as tumuli (cemetery) Illyrian, remains of old buildings, residencies and grave stones dating from Middle age. By building objects for tourists we would insure opening of the area and its resources towards tourists and it would valorize, in any aspect, rural, recreational, hunting, fishing, sports, village and ecological tourism.
\end{abstract}

Keywords: tourist potential, Ferizaj, development of tourist sector, Bifurcation

\section{Introduction}

Ferizaj has sufficient potential for the development of cultural, nature and recreation tourism. Among the potentials of the development of local tourism are beautiful mountains of Sharr ,the valley of the river Nerodime ,bifurcation ,the union of two rivers etc. Ferizaj, compared with its surroundings, is relatively new town. One of the most important factors from historic past to the formation of the city of Ferizaj and its economic development is the construction of the railway line (1874) and a railway station that is very important for the transportation of passengers and goods, which also influenced the changes of the view of the place, which today has been transformed into the city (http://kk.rks-gov.net/ferizaj/Cityguide/History.aspx)

Ferizaj has a convenient geographical and economic position. It lies in the southern part of Rrafshi Kosoves and has an area of $344.71 \mathrm{~km} .2$ and counts more than 107,000 inhabitants. Ferizaj shares borders with seven other municipalities (Komunat e Kosoves, Profil i shkurter, Asociacioni i Komunave te Kosoves). Ferizaj distance from Prishtina is $36 \mathrm{~km}$, and $48 \mathrm{~km}$ from Skopje. The most important thing of Ferizaj is the bifurcation of the river Nerodime that is rare hydrographic phenomenon in the world, waters of which are divided and deposited in two direction ,one into Aegean Sea and one into the Black Sea.The landscape of the municipality of Ferizaj is characterized by three natural entirety : Sharr Mountains in the west and northwest ,Rrafshi Kosoves and some hilly-mountains areas in the east.

\section{Natural Resources}

The municipality of Ferizaj is rich with natural resources. The Complex Sharr of mountain ridges is rich in flora and fauna ,as well as in characteristic relief of a specific kind. So far are registered more than 2000 kind of plants ,a number that represents $25 \%$ of Balkans flora and $18 \%$ of Europeans flora (Strategjia e Zhvillimit Ekonomik Lokal 2005-200). On the basis of existing data about $29 \%$ of these species are endemic, while about $18 \%$ are sub endemic . Of the total number of these species recorded in the Sharr Mountains, 86 species have been declared of international importance, 26 species are included in the European red list, while IUCN 32 kind of plants are in red list of threatened plants to extinction. Sharr fauna is diverse, registered groups are: Mammals: 32 species, Birds:180 species, Reptiles: 13 species, Amphibian : 10 species, Fish: 7 species and Butterfly: 144 species (H Halili, Koncepti i Marketingut si pjesë e menaxhimit të Parkut Kombëtar Sharri), The municipality of Ferizaj is characterized by the presence of the migratory birds, like stork that builds interesting and attractive nests. (villages Greme (Topojan), Lloshkobare Surqina and the valley of Nerodime etc.). High forests in the mountains of Sharr, provide living conditions for large mammals such as Dun Bear (UrsusArktus), lynx (lynx - lynx), deer (kapreolus-kapreolus), Chamois (Rupicapra, Rupicapra), then many kinds of predatory and songbirds, very important for the ornitofauna of Kosovo and beyond such as : Mountain Eagle (Aquila chrysaetos),White 
Polish Falcon (Falco Naummani), wild chickens (Tetrao urogallus).

\section{Water Resources}

In Ferizaj surface waters flow along the river Neredime, which is an important branch of the river Lepenc. Neredime River consists of two rivers, big river and small river, originating in southern part of Neredeme mountain, at an altitude of $600 \mathrm{~m}$. The length of the river Neredime is $29 \mathrm{~km}$, the surface of the basin is $209 \mathrm{~km} 2$, while the average speed is $0.9 \mathrm{~m}^{3} / \mathrm{sec}$. The flow of the river Neredime is weak because of the bifurcation. Other surface waters in the territory of the Municipality of Ferizaj, are being used for irrigation, the river of Pleshina and Greme, that join Neredime River near the village of Gurez (branch of Neredime river that flows into the river Lepenc).

\section{Climate}

The municipality of Ferizaj is characterized by a continental climate. The average annual temperature is $9.9^{\circ} \mathrm{C}$. Were warmer months are July and August with average temperature $18.9^{\circ} \mathrm{C}$. The coldest month is January with the average temperature of $-2.6^{\circ} \mathrm{C}$. Maximum temperature of the air is $32.5^{\circ} \mathrm{C}$ in July, while the minimum is $-14.0^{\circ} \mathrm{C}$ in January. The highest average humidity ranges from $85.0 \%$ to $87.0 \%$, in the months of December and January, while the lower is in April and May and it goes from $68.2 \%$ to 68.4 . On average, a year has $731.3 \mathrm{~mm}$ of rainfall in the municipality of Ferizaj. May is the month with the most rainfalls to $105.6 \mathrm{~mm}$, and with the least rainfalls is August to $42.2 \mathrm{~mm}$. The land of Ferizaj is covered with snow in average 51.8 days. In Ferizaj mostly blow northwestern winds (N-248), Northern (N142 ) and southeast winds (SE-147). East winds blow less (E-22).

\section{Resources for the development of cultural tourism in Ferizaj}

Ferizaj, as the city is new but its surroundings have been inhabited since ancient time and there is an evidence of numerous findings, which have not been explored sufficiently by scientists. However, occasional researches that are made as in Vaross, Komogllave, Jezerc, Nerodime and other villages by archeologists and ethnographers said that the municipality has a great potential of valuable buildings from antiquity. Especially Dardan Church, the ruins of which are located between villages of Komogllava and Sojeva Old Village, Water Supply from the illyrian time in the village of Komogllave, which supplies drinking water even today for some families, Tuma illyrian (cemeteries) in village of Varosh,the ruins of old city in Jezerc, different ruins of different times in Nerodime, the bath of aristocratic family in Nerodime (N. Ferri, Banja e familjes aristokrate ne Nerodime) etc. Ferizaj has many buildings and cultural institutions like the House of Culture "Hivzi Sylejmani".", built in 1924 (one of the oldest buildings in the city), the Public City Library, built in 1928, the Professional Theatre" Adriana Abdullahu ", the Art Gallery, the Cinema of the city, the Historical Archives of the City and the Museum of the City ( Komuna e Ferizait, Udhërrëfyesi, 2009). Ferizaj is known for its old Orthodox church and mosque that are (close to each other) and show the tradition of tolerance and multi-ethnicity (Komuna Ferizajt, Strategjia Zhvillimore Lokale, Mars 2009). In Ferizaj there are several traditional manifestations of national character as Culture month , Kosovo Theatre Festival, the Festival "Kosovarja kendon",festival "Fëmijët e gëzuar", Carnival,festival "Sofra ferizajase ", and the festival of "Recital Poets of Kosova ".All these cultural activities represents potential resources for the development of cultural tourism.

Table. Protected areas in Ferizaj, (Plani Lokal i Veprimit ne Mjedis Komuna Ferizajt, 2009-2015)

\begin{tabular}{lll}
\hline Facility Name & Year Ad & Category of defense \\
\hline $\begin{array}{l}\text { 1. River Bifurcation Nero dime } \\
\text { 2. Tourist Area 120 ha }\end{array}$ & 01.Nr.4603, dt: 17.09.2002 & $\begin{array}{l}\text { Natural Special Reserve } \\
\text { the greater area is declared the space between the small and } \\
\text { the neredime }\end{array}$ \\
\hline
\end{tabular}

\section{The bifurcation of River Nerodime}

The bifurcation of river Nerodime represents the only example in Europe of a river that flows into two seas, like Orinoco River in South America that represents it and are only two same cases in the world. The river originates in the mountains of Jezerc and is formed of two main branches that join the village Nerodime and continues the journey to the dam, where the first bifurcation occurs. The Bifurcation of river Nerodime irreversible splits into two branches, which 
flow in two different seas. North Branch (left branch) flows into river Sitnica and continues its route to river Iber , Morava and through Danube flows into the Black Sea, while the southern branch (right branch) first joins one branch of the river Nerodime, which is divided to concrete dam (distance $1300 \mathrm{~m}$ ) and continue along the path into the river Lepenc and through river Vardar flows in the Aegean Sea. This curiosity of nature is quite attractive for researchers and visitors and it has educational , scientific and touristic importance. Since 1979 it has been under legal protection as special nature reserve (Vlerat e Trashigimisë Natyrore të Kosovës, Ministria e Mjedisit dhe Planifikimit Hapsinor).

\section{How to orient future development of tourism in Ferizaj}

The future development of tourism activities in Ferizaj should be planned. Although the area has a rich natural and cultural heritage, for further development of these activities is basic essential material based on touristic buildings and of qualitative structure of employees. The phenomenon of bifurcation is very important for the development of tourism in the Municipality of Ferizaj, this wealth will be promoted and complemented.

For future development of the tourism industry in Ferizaj, it is necessary to develop a strategy for the development of all aspects of tourism and Ferizaj has optimal conditions.

Nerodime river with its branches offers excellent opportunities for development of tourism and recreation-sports. Also this river is very important for the development of scientific tourism, only with one research have been identified 116 different species of different algae (K. Kurteshi, Algological Investigation in River Nerodime during the Summer season 2011).

Built pools along the river provides ideal conditions for collective recreation swimming. Recently, there is a growing interest of people for the adventure tourism.

The program for the development of tourism in the area along the river Nerodimja should be treated with priority matter with a complementary offer which should include anthropogenic reasons, historical and cultural inheritance, folk festivals and excursions, the renovation of the banks of river Nerodime, the development of fishing and the organization of sport races, the wealth of river Nerodime makes possible the development of fishing tourism and sport as well as the commercial tourism offers of Ferizaj. For general affirmation of fishing are required commitments in the enrichment of fishing stocks, the organization of fishing activities and the planned development of fishing.

Possible development potential can show also the promotion of transit tourism. Tourist transit directions are special and they are specific areas of tourist offer along the important corridors of local routes and international routes within touristic regions also like a special offer (Raport i sektorial i zhvillimit hapësinor për sektorin e turizmit). For the development of touristic tourism and its traffic main importance have those segments of roads : Prishtina - Ferizaj Skopje and vice versa, Pristina - Ferizaj - Doganaj-Tetovo and vice versa,Prishtina - Ferizaj - Shterpce-Prizren and vice versa. Also those segments are important :Skopje - Ferizaj - Shtime - Qaf of Dule (inclusion on the highway) - Durres, Tirana and Ferizaj - Gjilan- Preshevo and vice versa

Hunting is an important factor of tourist offer of Ferizaj. To develop hunting tourism in Ferizaj it is necessary to regulate and to provide hunting territory (country-hunting). This includes the revitalization of hunting facilities and renovation of hunting equipment. To increase the flow of foreign tourists at the hunting grounds, essential are housing capacity enriched with variety of specialties of local cuisine.

Predispositions for the development of camp-tourism are ideal. The territory of Jezerc provides favorable conditions for the construction of summer houses and bungalows. This area is suitable to accommodate people that love nature, camping and the development of youth tourism. Suitable terrains for camping, recreation, and for construction of summer-houses are also in Burrnik, Gaçkë and Pleshinë.

Favorable terrains for the development of winter tourism have Burrniku and Gaçka. Fresh air of these forest areas, the soft slopes of the rivers are ideal for rest and recreation. With a good organization there you can start an artisan workshops, collaborations with artists, exhibitions and similar items. In this way we will keep a part of the tradition of this area which people are forgetting it. Settlements along the river Nerodime have favorable predispositions because they offer the opportunity to stay at the numerous built hotels . Curiosities of certain areas, the diversity of agricultural products, property with orchards and medicinal plants, are real base to prove that this form of tourism offer has prospect.

One of the strategic goals among the local development strategy was the promotion of rural tourism with native features based on family economies (Komuna Ferizajt, Strategjia Zhvillimore Lokale), but it should be concluded that this strategic goal is not achieved much less is not developed a concrete medium-term strategy or action plan to achieve this goal. 


\section{Conslucion}

Opportunities for economic recovery of municipalities are directly related to the efficient use of natural resources. Tourist activities will create space for some economic sectors to expand their market and to pass goods and services like agriculture does through products for catering ,handcrafts ,trade and transportation through offering services to tourists, etc.

In reviewing the basic characteristics and factors that affect the development of the tourism industry, it is necessary to explore the possibility and justification on the construction of a hotel complex in the gorge of Nerodime , along with a medical center for the future development of health tourism.

Bifurcation environment should be combined into a tourist building, with space for a summer garden in which will be organized presentations, promotions or fashion shows accompanied by the offer of local cuisine, and additionally to this should be created a Collection museum with ethnological value of the Ferizaj. This tourist buildings will become an important driving force in the development of tourism and hospitality.

Regarding to a mountain tourism, tourism development in Jezerc camping, in this mountain area which slowly is being transformed into a place for the development of rural tourism, with good conditions for accommodation of visitors, should be regulated the fields that enable the development of a series sports and recreational activities. The relief of Jezerc provides good conditions for cycling, nature with numerous mountains, meadows and fountains gives the opportunity to march along long and short paths. Nature provides recreation opportunities with aeronautical aircraft, offers opportunities for climbing , riding , hunting, fishing, skiing etc. To all this we should also add willingness of more than 53 households to offer residential rooms, prepare traditional foods and offer Albanian generosity and hospitality. This is a place where visitors can feel satisfied. Jezerci should try to capitalize on all of its assets, to maintain them and invite visitors to come and enjoy them. There should be noted also another activity such as the collection and gathering of wild fruit, medicinal plants, mushrooms, strawberries and other fruit of mountains.

Like this Ferizaj can become a center of research of both domestic and foreign customers, in terms of recreation, place of living and health tourism. Foreign tourists have shown interest for Ferizaj despite this a significant number of residents of EU countries living in Ferizaj, so it is necessary to create conditions for better participation in the period of holiday (summer and winter ), religious holidays and other occasions .

In conclusion Ferizaj has many interesting places to visit as bifurcation, Mulliri i Nikes, Water Factory (Pleshine), Sharr mountains and it part that stretches in Ferizaj municipality - Burrniku, Nerodimka, Jezerci,Parku i Lirise etc. and if those resources will be promoted and complemented it is realistic to say that tourism in Ferizaj can be one of the important branches of the economy, that leads the creation of new jobs and employment of professional staff of tourism and hospitality. So tourism has its opportunities in the development of economy in Ferizaj and will this opportunity be used it remains to be seen in the future.

\section{References}

Ferizaj municipality, the Local Development Strategy, March 2009, LAG bifurcation;

$\mathrm{H}$. Halili, "The concept of marketing as part of management in the National Park Sharri", International Journal of scientific and research "DISCUSSION", November 2014, Tetovo, Macedonia;

K. Kurteshi, I. Vehapi, M. Ismajle, I. Vllasaku, "Algological Investigation in River Nerodime during the Summer season 2011" New Knowledge journal of science, Anniversary International Scientific and Applied Conference- UARD, Bulgaria 2012;

Local Action Plan on Environment Municipality Ferizaj, 2009-2015, Ferizaj June 2009;

Local Economic Development Strategy 2005-2007, March 2005, Ferizaj;

Municipalities of Kosovo, Profile Brief, the Association of Municipalities of Kosovo, June 2008;

Municipality of Ferizait, Roadmap 2009, Ferizaj;

N. Ferri, "Banja aristocratic family in Nerodime", Koha Ditore, Kosovo, 2015;

Natural Heritage values of Kosovo, the Ministry of Environment and Spatial Planning, Pristina, 2005;

Report sectoral spatial development of the tourism sector, tourism development program and spatial regulation of tourism Pristina, September 2004;

Urban Development Plan of Ferizaj, Ferizaj municipality - 12/2008;

http://kk.rks-gov.net/ferizaj/City-guide/History.aspx; 